\title{
Lead-free Solder Assembly: Impact and Opportunity
}

\author{
Edwin Bradley \\ Motorola \\ 8000 W. Sunrise Blvd. \\ Plantation, FL 33322 \\ edwin.bradley@motorola.com
}

\begin{abstract}
There has been major interest in Lead-free soldering within the electronics assembly industry for the last several years, and this will continue with the agreement on the language and implementation dates of the WEEE/ROHS legislation in the EU. This paper will focus on several topics critical to the implementation of lead-free soldering. These topics include the impact of Tin-silver-copper as the alloy of choice for leadfree assembly both with respect to component and solder joint reliability, temperature exposure, and lead-free finishes. Results from the recently completed NEMI Lead-free Solder Project, the author's own work and other published data are discussed.
\end{abstract}

\section{Background}

The recent history of lead-free solder for electronics assembly has been a tumultuous period of research on the technical merits of various candidate alloys as well as and discussion of the actual benefits of eliminating lead from solder. Much of the initial push for lead-free came from Japanese electronics companies that perceived lead-free soldering as an opportunity to differentiate their product to consumers and increase sales [1]. Around the same time, the EU proposed legislation that are now known as WEEE (Waste from Electrical and Electronic Equipment) and ROHS (Restriction of Hazardous Substances Directive) [2,3]. The WEEE sets targets for take-back recycling while ROHS would severely limit the use of lead in electronics. The language of the legislation was finalized in late 2002, and if passed, the restrictions on lead would be enforced as of July 1, 2006. The bulk of electronic products are affected by the lead ban in ROHS, with only the following applications exempted at the present time:

- Lead in glass of cathode ray tubes, electronic components and fluorescent tubes.

- Lead as an alloying element in steel containing up to $0.35 \%$ lead by weight, aluminium containing up to $0.4 \%$ lead by weight, and as a copper alloy containing up to $4 \%$ lead by weight.

- Lead in high melting temperature type solders (i.e. tinlead solder alloys containing more than $85 \%$ lead).

- Lead in solders for servers, storage and storage array systems (exemption granted until 2010).

- Lead in solders for network infrastructure equipment for switching, signaling, transmission as well as network management for telecommunication.

- Lead in electronic ceramic parts (e.g. piezoelectronic devices).

This has driven substantial interest in lead-free solder development around the world including within the US. Several industry consortia have investigated the Lead-free issue including those associated with NEMI [4], NCMS [5,6], and IDEALS [7]. The NEMI Lead-free solder project was a three-year endeavor that focused on the technical challenges of lead-free implementation. A large number of companies including OEM, EMS, supply chain, and governmental agencies were active members and gave a broad perspective on what issues to focus on. There has also been work looking at the costs and to what extent there are environmental benefits of leaded solder elimination $[8,9]$. The legislative mandate of ROHS will push lead-free electronics assembly into the mainstream regardless of the scientific merits.

\section{Lead-free Alloys: Manufacturability and Reliability}

The main issue with Lead-free soldering is to comparably replace the $\mathrm{Sn}-\mathrm{Pb}$ solder with one that has the requisite processing and mechanical properties. The long supremacy of $\mathrm{Sn}-\mathrm{Pb}$ owes itself to the relatively low processing temperature along with reasonable mechanical properties. Although $\mathrm{Sn}-\mathrm{Pb}$ has some issues, such as with gold embrittlement, it is compatible with numerous metal finishes and has a reasonably low melting point of $183^{\circ} \mathrm{C}$.

An initial study of lead-free alloys by NCMS [5] showed that of the numerous solder alloys examined, only a few met the initial baseline requirements of manufacturability, cost, availability, and reliability. The alloys recommended for further study included $\mathrm{Sn}-3.5 \mathrm{Ag}, \mathrm{Sn}-58 \mathrm{Bi}$, and $\mathrm{Sn}-3.5 \mathrm{Ag}$ 4.8Bi. However, the Sn-Ag eutectic melts at $221^{\circ} \mathrm{C}$, (approx. $38^{\circ} \mathrm{C}$ above eutectic $\mathrm{Sn}-\mathrm{Pb}$ ) and much subsequent work has focused on alloying additions that lower the Sn-Ag melting temperature but preserve or enhance its mechanical properties. The two alloy groups that have received the most attention are $\mathrm{Sn}-\mathrm{Ag}-\mathrm{Bi}$ and $\mathrm{Sn}-\mathrm{Ag}-\mathrm{Cu}$.

Japanese companies have heavily investigated $\mathrm{Sn}-\mathrm{Bi}$ alloys for $\mathrm{Sn}-\mathrm{Pb}$ replacement [10]. Bismuth is more effective in lowering the $\mathrm{Sn}$ melting temperature than $\mathrm{Ag}$ or $\mathrm{Cu}$. However there are some issues that make $\mathrm{Bi}$ less than desirable as a general lead-free solder replacement. One concern is the potential of $\mathrm{Bi}$ alloying with $\mathrm{Sn}-\mathrm{Pb}$ to form a low melting point eutectic [11] or peretectic as shown in Table 1. Anytime a lower melting point constituent forms in a solder joint it can greatly decrease reliability [12]. A couple of investigations have examined the interaction of $\mathrm{Bi}$ and $\mathrm{Pb}$ in $\mathrm{Sn}-\mathrm{Ag}$ solders $[13,14]$. Figure 1 shows the first onset of melting for various $\mathrm{Sn}-\mathrm{Ag}$ solders with and without $\mathrm{Pb}$. The presence of $\mathrm{Pb}$ and $\mathrm{Bi}$ in $\mathrm{Sn}-\mathrm{Ag}$ solders lowers the first onset of melting compared to $\mathrm{Sn}-\mathrm{Ag}$ without Bi. An example of the reduced reliability of $\mathrm{Sn}-\mathrm{Ag}-\mathrm{Bi}$ solders as a function of $\mathrm{Bi}$ content when assembled to $\mathrm{Sn}-\mathrm{Pb}$ plated TSOPs tested at -55 to $125^{\circ} \mathrm{C}$ is shown in Figure 2 .

Table 1. Several Pb-based ternary constituents

\begin{tabular}{|c|c|c|}
\hline $\begin{array}{c}\text { Composition, } \\
\text { wt } \%\end{array}$ & Type & $\begin{array}{c}\text { Melt Temp, } \\
{ }^{\circ} \mathrm{C}\end{array}$ \\
\hline Sn- $18 \mathrm{Bi}-40 \mathrm{~Pb}$ & Peretectic & 137 \\
\hline
\end{tabular}




\begin{tabular}{|c|c|c|}
\hline Sn-51Bi-32Pb & Eutectic & 96 \\
\hline $\mathrm{Sn}-36 \mathrm{~Pb}-2 \mathrm{Ag}$ & Eutectic & 179 \\
\hline
\end{tabular}

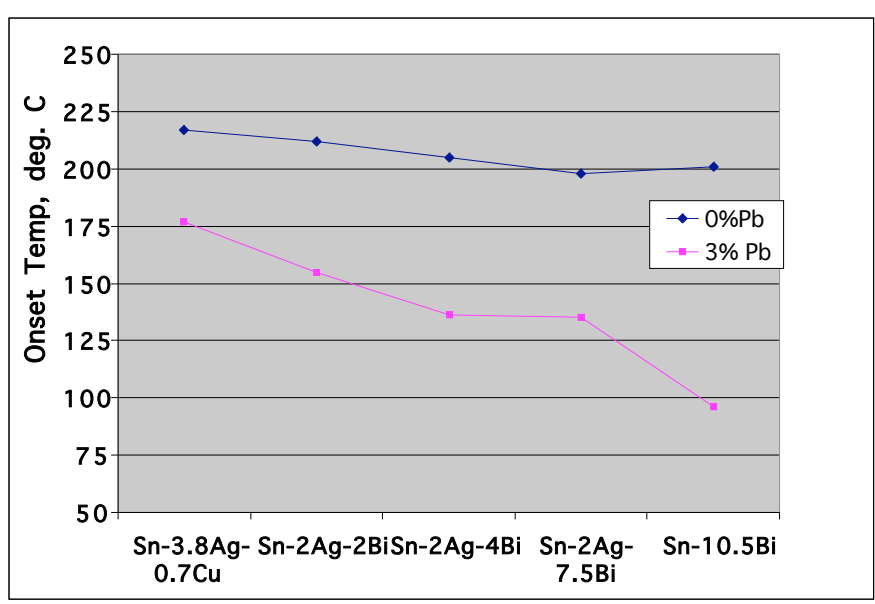

Figure 1. Minimum onset temperatures from DSC testing for various $\mathrm{Sn}-\mathrm{Ag}$ alloys for $0 \%$ and $3 \% \mathrm{~Pb}$.

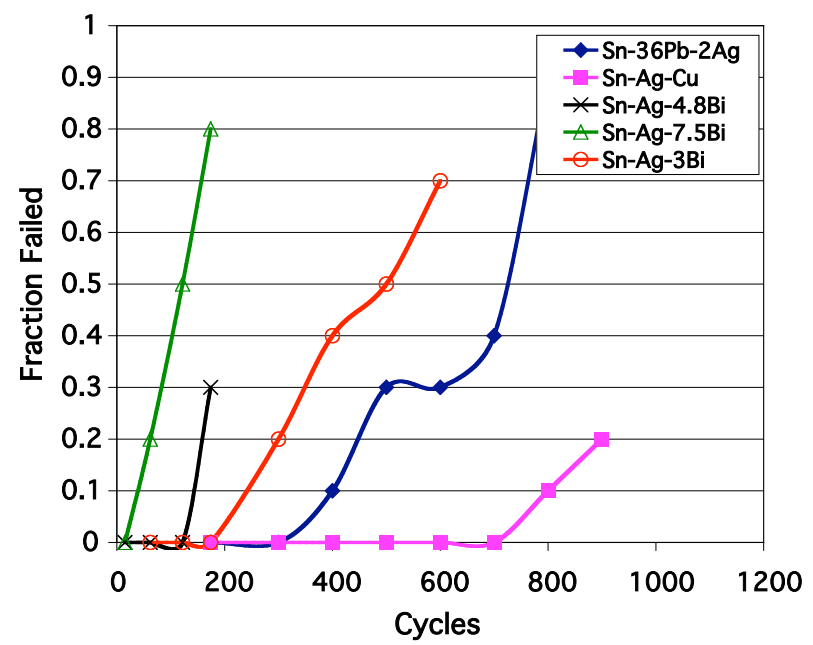

Figure 2. Reliability data for TSOPs assembled to electroless nickel immersion gold boards cycled from -55 to $125^{\circ} \mathrm{C}$

\section{Tin-Silver-Copper (Sn-Ag-Cu)}

$\mathrm{Sn}-\mathrm{Ag}-\mathrm{Cu}$ alloys have emerged as the most promising lead-free alternative for reflow assembly. JEITA recommends $\mathrm{Sn}-3 \mathrm{Ag}-0.5 \mathrm{Cu}$ [15] while NEMI [16] and SOLDERTEC [17] have advocated Sn-3.9Ag-0.6Cu and Sn-(3.4-4.1)Ag-(0.45$0.9) \mathrm{Cu}$ respectively. Ideally, one alloy would be the primary $\mathrm{Pb}$-free alloy for electronics assembly, although there may always be niche applications that may require other alloy compositions. Realize that presently both $\mathrm{Sn}-37 \mathrm{~Pb}$ and $\mathrm{Sn}-$ $36 \mathrm{~Pb}-2 \mathrm{Ag}$ are used in electronic assemblies, with the binary commanding a larger share of the market. The difference compositionally between $\mathrm{Sn}-3 \mathrm{Ag}-0.5 \mathrm{Cu}$ and $\mathrm{Sn}-3.9 \mathrm{Ag}-0.6 \mathrm{Cu}$ is less than that of $\mathrm{Sn}-37 \mathrm{~Pb}$ and $\mathrm{Sn}-36 \mathrm{~Pb}-2 \mathrm{Ag}$. It is likely that general experience over time will determine which alloy emerges as the primary lead-free alloy going forward.

\section{Reliability of Sn-Ag-Cu Solders}

One of the main issues with moving to a lead-free solder is to know and understand its effect on solder joint reliability. There have been innumerable studies published on $\mathrm{Sn}-\mathrm{Pb}$ reliability, along with years of experience that give tremendous confidence of its field performance. Any alternative solder system suffers by comparison, but there has been much work recently to fill the gap of experimental results. The NEMI Lead-free solder project [18] evaluated the thermal cycling reliability of six different components: 256 PBGA, 256 CBGA, 48 TSOP, 2512 resistor, 169 CSP and 208 CSP and a summary of the results are shown in Table 2. The table indicates how either the lead-free $(\mathrm{Sn}-3.9 \mathrm{Ag}-0.6 \mathrm{Cu}$ paste + lead-free finish) or mixed $(\mathrm{Sn}-\mathrm{Ag}-\mathrm{Cu}$ paste $+\mathrm{Sn}-\mathrm{Pb}$ finish) compared to the $\mathrm{Sn}-\mathrm{Pb}$ standard assembly ( $\mathrm{Sn}-\mathrm{Pb}$ paste + finish) on immersion silver boards. Each test condition typically contained 32 components and was tested to at least $50 \%$ failure and the results were evaluated using Weibull analysis at a $95 \%$ confidence level. The ratio of the eta values (comparing $\mathrm{Sn}-\mathrm{Ag}-\mathrm{Cu}$ to $\mathrm{Sn}-\mathrm{Pb}$ ) from the Weibull analyses for -40 to $125 \mathrm{C}$ tests are plotted in Figure 3 and all are at or above 1. The results show that the $\mathrm{Sn}-3.9 \mathrm{Ag}-0.6 \mathrm{Cu}$ alloy compares favorably to the $\mathrm{Sn}-37 \mathrm{~Pb}$ eutectic.

Table 2. Summary Results of the NEMI Thermal Cycling Evaluation

\begin{tabular}{|c|c|c|c|}
\hline Component & $\begin{array}{c}\text { Temp } \\
\text { Cycle, }{ }^{\circ} \mathrm{C}\end{array}$ & $\begin{array}{c}\text { Lead-free } \\
\text { vs. } \mathrm{Sn}-\mathrm{Pb}\end{array}$ & $\begin{array}{c}\text { Mixed vs. } \\
\mathrm{Sn}-\mathrm{Pb}\end{array}$ \\
\hline 48 TSOP & -40 to 125 & 0 & - \\
\hline $\begin{array}{c}2512 \\
\text { resistor }\end{array}$ & -40 to 125 & 0 & 0 \\
\hline 256 CBGA & 0 to 100 & + & - \\
\hline 256 PBGA & -40 to 125 & 0 & 0 \\
\hline 256 PBGA & 0 to 100 & 0 & 0 \\
\hline 169 CSP & -40 to 125 & + & + \\
\hline 169 CSP & 0 to 100 & + & 0 \\
\hline 208 CSP & -40 to 125 & + & 0 \\
\hline 208 CSP & 0 to 100 & + & + \\
\hline
\end{tabular}

+ statistically better than $\mathrm{Sn}-\mathrm{Pb}$, - statistically worse, $0=$ indeterminate

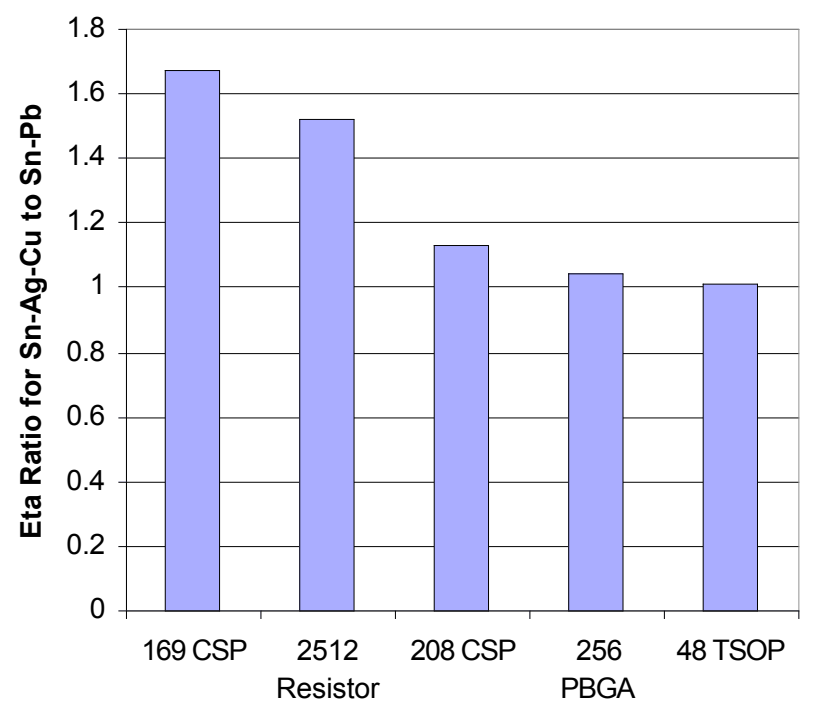


Figure 3. Calculated eta ratio from Weibull curves for Sn3.9Ag-0.6 Cu compared to $\mathrm{Sn}-37 \mathrm{~Pb}$ for NEMI thermal cycling tests at -40 to $125^{\circ} \mathrm{C}$.

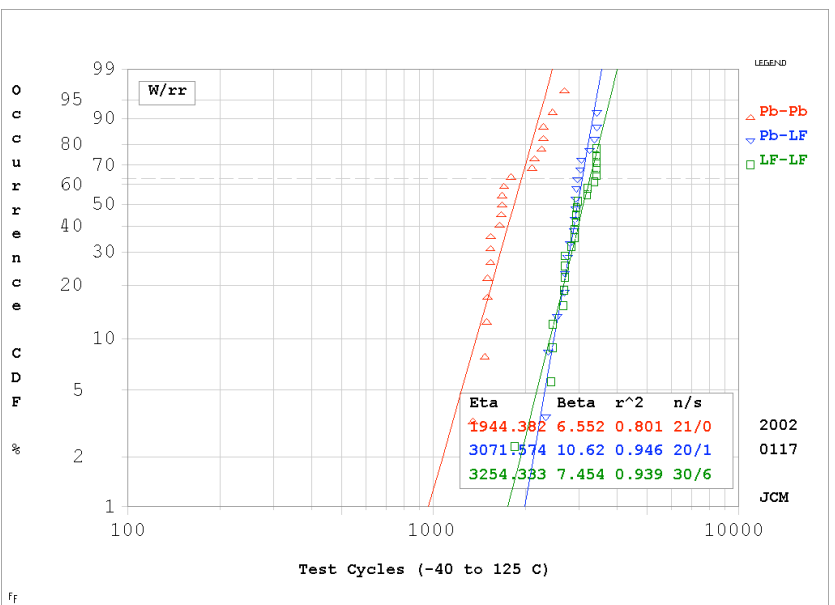

Figure 4. Weibull plot from NEMI testing of 169 CSPs cycled from -40 to $125^{\circ} \mathrm{C}$. Green $=\mathrm{Sn}-3.9 \mathrm{Ag}-0.6 \mathrm{Cu}$, Blue $=$ Mixed, $\mathrm{Red}=\mathrm{Sn}-37 \mathrm{~Pb}$.

The Weibull curves for the lead-free 169 CSP (Figure 4) are substantially better than $\mathrm{Sn}-\mathrm{Pb}$ both in mean time to failure as well as early failure. Overall, the NEMI results agree with other published reports that the $\mathrm{Sn}-\mathrm{Ag}-\mathrm{Cu}$ alloys, when assembled to lead-free terminations, are typically as reliable as $\mathrm{Sn}-\mathrm{Pb}$ eutectic in accelerated testing.

$\mathrm{Sn}-\mathrm{Ag}-\mathrm{Cu}$ has been shown to outperform high- $\mathrm{Pb} \mathrm{C} 4$ joints in CBGA assemblies [19]. Syed [20] showed consistently better results in thermal cycling for $\mathrm{Pb}$-free alloys. The findings also show that $\mathrm{Sn}-\mathrm{Ag}-\mathrm{Cu}$ alloys are proportionately better in thermal fatigue as the thermal cycling range decreases. Figure 5 shows the ratio of mean fatigue life for the two accelerated test conditions $\left(0\right.$ to $100^{\circ} \mathrm{C}$ and -40 to $125^{\circ} \mathrm{C}$ ) comparing $\mathrm{Sn}-\mathrm{Ag}-\mathrm{Cu}$ to $\mathrm{Sn}-\mathrm{Pb}$ for the Syed and NEMI results. A higher ratio indicates improved thermal cycling performance at the more benign test condition relative to the more extreme condition. $\mathrm{Sn}-\mathrm{Ag}-\mathrm{Cu}$ performs better relative to $\mathrm{Sn}-\mathrm{Pb}$ at the less extreme cycling conditions.

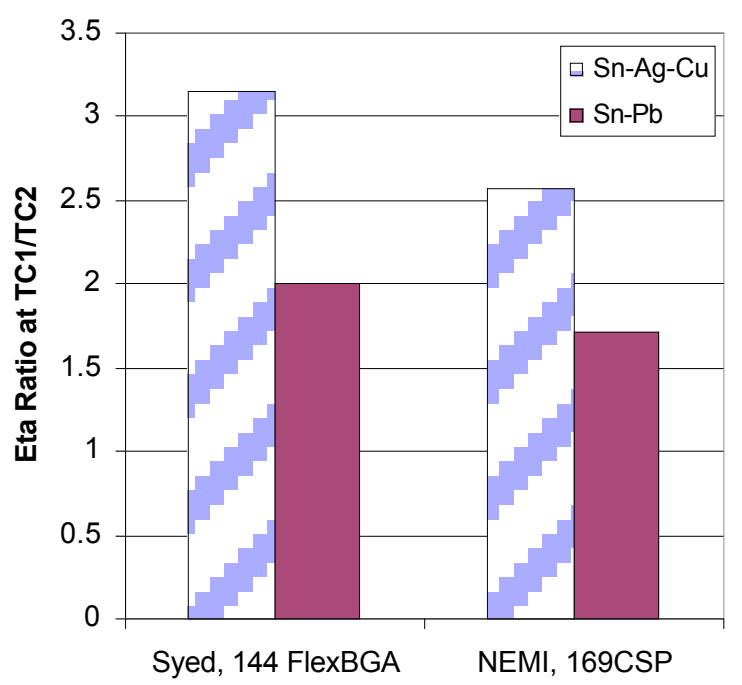

Figure 5. Eta ratio at two different thermal cycling conditions demonstrating the higher acceleration factor for $\mathrm{Sn}$ Ag-Cu compared to $\mathrm{Sn}-\mathrm{Pb}$. TC1 $=0$ to $100^{\circ} \mathrm{C}, \mathrm{TC} 2=-40$ to $125^{\circ} \mathrm{C}$.

There is limited published data for lead-free solders subjected to vibration or other isothermal cyclic fatigue conditions. Kanchanomai [21] performed isothermal straincontrolled fatigue tests and found that $\mathrm{Sn}-3.5 \mathrm{Ag}$ exhibited twice the cycles to failure for a given plastic strain range than $\mathrm{Sn}-37 \mathrm{~Pb}$ at room temperature.

As shown in Table 2 and Figure 2, $\mathrm{Pb}$ contamination in lead-free solder joints can adversely affect reliability of leadfree alloys. There are two ways a lead-free solder joint can contain more than trace amounts of lead: (1) lead-free finishes assembled with $\mathrm{Sn}-\mathrm{Pb}$ solder and (2) $\mathrm{Sn}-\mathrm{Pb}$ finishes assembled with lead-free solder. For type 1 assemblies there are substantial data and experience assembling non-BGA style components with lead-free finishes such as gold, Ni-Pd, and matte tin using $\mathrm{Sn}-\mathrm{Pb}$ solder, but little information with leadfree BGAs and $\mathrm{Sn}-\mathrm{Pb}$ paste. Type 2 was expected by the NEMI project to be the more common manufacturing scenario and was chosen for testing. As shown in Table 3, type 2 mixed cells are richer in $\mathrm{Pb}$ for BGAs compared to leadframe or leadless components, and so care must be taken if extrapolating mixed cell results to other component types. Table 4 shows the nominal composition of the three types of assemblies for two components tested by NEMI.

In the NEMI study, the mixed cell is statistically lower than the corresponding $\mathrm{Sn}-\mathrm{Pb}$ cell for two of the nine test conditions, and is statistically higher for two as well [22]. Analysis of the microstructure of the mixed assembly BGA components did not show any macroscopic $\mathrm{Pb}$ or $\mathrm{Ag}$ compositional gradients within the solder joints, and the fatigue crack path is similar in both cases. Greater detailed analysis is needed to understand the root cause of the variation and determine the relative importance of composition versus assembly process. 
Table 3. Comparison of $\mathrm{Pb}$ content for different mixed assembly types

\begin{tabular}{|c|c|c|}
\hline & BGA style & $\begin{array}{c}\text { Leadframe / } \\
\text { leadless style }\end{array}$ \\
\hline $\begin{array}{c}\text { Lead-free finish }+ \text { Sn- } \\
\mathrm{Pb} \text { solder (type } 1)\end{array}$ & $\begin{array}{c}\text { Low } \mathrm{Pb} \\
\text { content }\end{array}$ & $\begin{array}{c}\text { High } \mathrm{Pb} \\
\text { content }\end{array}$ \\
\hline $\begin{array}{c}\text { Sn-Pb finish }+ \text { lead- } \\
\text { free paste (type } 2)\end{array}$ & $\begin{array}{c}\text { High } \mathrm{Pb} \\
\text { content }\end{array}$ & $\begin{array}{c}\text { Low } \mathrm{Pb} \\
\text { content }\end{array}$ \\
\hline
\end{tabular}

Table 4. Nominal $\mathrm{Pb}$ content (wt \%) of 2512 resistor and 169 CSP in from NEMI testing

\begin{tabular}{|c|c|c|}
\hline & $169 \mathrm{CSP}$ & 2512 Resistor \\
\hline Sn-Ag-Cu & Sn-3.9Ag-0.6Cu & Sn-3.7Ag-0.6Cu \\
assembly & & \\
\hline Sn-Pb finish + & Sn-32.7Pb- & Sn-0.6Pb- \\
Sn-Ag-Cu paste & $0.45 \mathrm{Ag}-0.07 \mathrm{Cu}$ & $3.7 \mathrm{Ag}-0.6 \mathrm{Cu}$ \\
\hline Sn-Pb assembly & $\mathrm{Sn}-37.0 \mathrm{~Pb}$ & $\mathrm{Sn}-35.7 \mathrm{~Pb}$ \\
\hline
\end{tabular}

\section{Effect of Gold in Sn-Ag-Cu Solders}

Another positive result with $\mathrm{Sn}-\mathrm{Ag}-\mathrm{Cu}$ is that it appears to be more resistant to gold embrittlement than $\mathrm{Sn}-\mathrm{Pb}$. In Figure 6 are the bend test results of Ni-Au finish LCCCs assembled to OSP finish PCBs. The strength of the joints is substantially higher for the $\mathrm{Sn}-\mathrm{Ag}-\mathrm{Cu}$ versus $\mathrm{Sn}-\mathrm{Pb}$, and the failure mode is changed from a partially brittle joint separation at the $\mathrm{AuSn}_{4}$ plates with the $\mathrm{Sn}-\mathrm{Pb}$ to a ductile tearing with the $\mathrm{Sn}-\mathrm{Ag}-\mathrm{Cu}$. The microstructure of the $\mathrm{Sn}-\mathrm{Pb}$ joints has numerous plates of $\mathrm{AuSn}_{4}$ intermetallic (Figure 7) that contributed to the failure while the lead-free joint shows no such $\mathrm{AuSn}_{4}$ plate morphology.

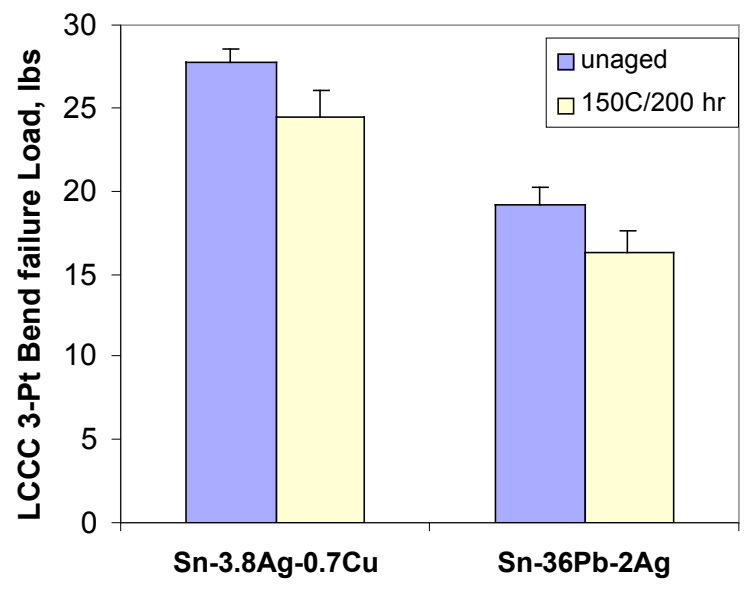

Figure 6. LCCC bend tests results.

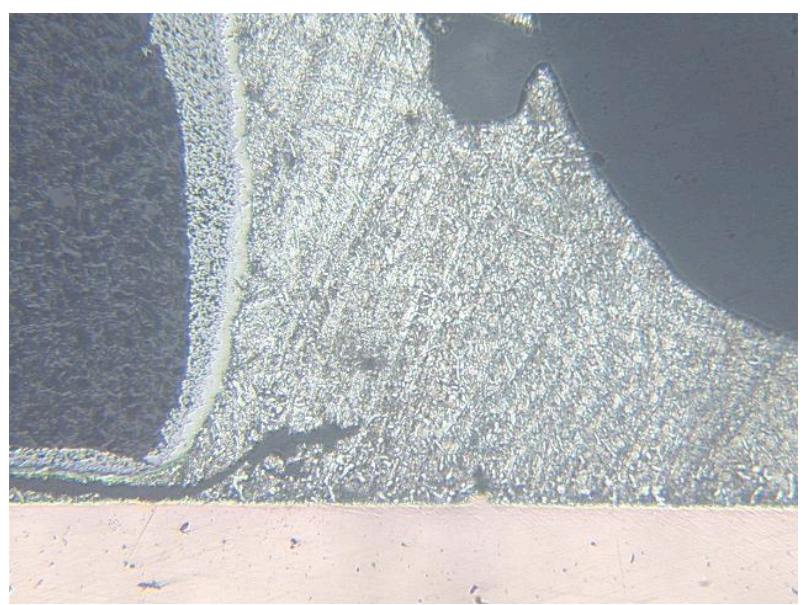

(a)

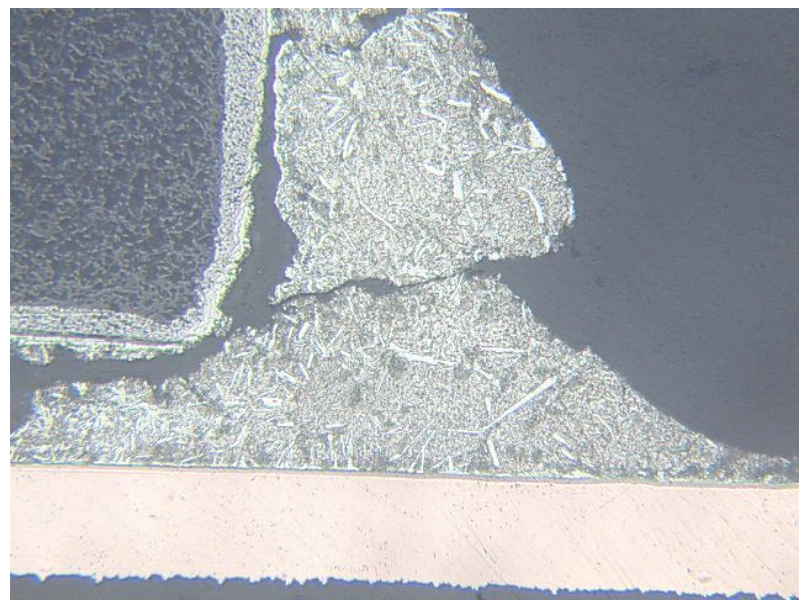

(b)

Figure 7. Etched microstructures of unaged LCCC solder joints after bend loading. The assemblies were made with a) $\mathrm{Sn}-\mathrm{Ag}-\mathrm{Cu}$ and b) Sn-Pb solder paste. Note that the $\mathrm{Sn}-\mathrm{Pb}$ has numerous plates of $\mathrm{AuSn}_{4}$ intermetallic that contributed to the failure while the lead-free solder joint does not have a similar microstructure.

\section{Effect of Lead-free Assembly Temperatures on Components}

Given that the vast majority of companies have migrated to $\mathrm{Sn}-\mathrm{Ag}-\mathrm{Cu}$, the major roadblock for implementation is that some components have trouble meeting the higher processing temperatures. Applying the typical reflow temperature process delta used with $\mathrm{Sn}-\mathrm{Pb}$ to $\mathrm{Sn}-\mathrm{Ag}-\mathrm{Cu}$, one can quickly calculate that a similar reflow peak for $\mathrm{Sn}-\mathrm{Ag}-\mathrm{Cu}$ would be around $260^{\circ} \mathrm{C}$, and this was proposed by NEMI as a good target for development efforts. $[23,24]$ Initial characterization has shown that certain parts are more robust than others with respect to the higher temperatures [25]. Swan [26] evaluated a number of component types and found many were capable of higher temperature reflow at MSL levels of 3 and higher.

Some of the components that are susceptible to the Sn$\mathrm{Ag}-\mathrm{Cu}$ assembly temperatures are electrolytic capacitors, connectors, opto-electronics, and older style plastic components. Recently, a number of companies have been issued press releases stating the availability of lead-free components that meet $260^{\circ} \mathrm{C}$, and this shows that the 
development efforts are making progress. The pressure on component suppliers is developing components that work at the higher temperatures while adding minimal cost.

\section{Component Leadframe Composition}

The vast majority of component leadframes are $\mathrm{Sn}-\mathrm{Pb}$ plated, and BGAs typically use $\mathrm{Sn}-37 \mathrm{~Pb}$ or $\mathrm{Sn}-36 \mathrm{~Pb}-2 \mathrm{Ag}$ spheres. Therefore, a major issue is the conversion of component terminations to lead-free alternatives. There are many existing types of lead-free component finishes (e.g. nickel-palladium, gold, and matte tin) that are lead-free. However, the cost of palladium is quite high and in recent years has often surpassed that of gold, reaching spot prices over $\$ 1000$ (US) per ounce. As a result, most recent efforts are focused on tin-based plating alternatives including tin, tincopper, tin-silver, and tin-bismuth.

The two most popular choices are tin (US/Europe) and tinbismuth (Japan). There is also concern with the propensity of tin whisker formation for these tin-based chemistries that is the focus of two NEMI projects [27]. An additional issue with tin-bismuth plating includes backward compatibility with $\mathrm{Sn}-\mathrm{Pb}$ assembly. The levels of $\mathrm{Bi}$ deposited are nominally low (approx. 2-3\%), so the risk of $\mathrm{Sn}-\mathrm{Pb}-\mathrm{Bi}$ eutectic formation is low, but process variations could possibly allow for microstructures that contain that. However, the author is not aware of any papers to date reporting reliability problems with $\mathrm{Sn}-\mathrm{Bi}$ plating assembled with Sn-Pb solder. [28]

\section{Lead-free Assembly Experience}

Only a few articles have been published on lead-free manufacturing of actual products [29,30] and not many products have been identified as being lead-free. Japanese manufacturers has been much more active and have published roadmaps showing conversion to lead-free for many products within the next few years.

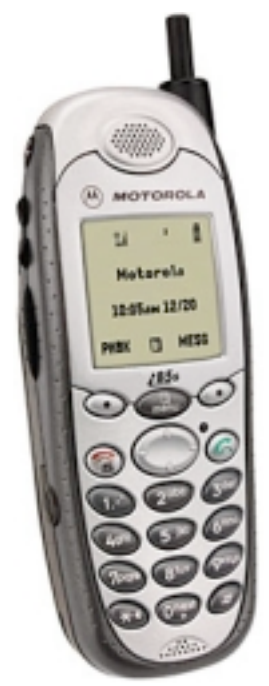

Figure 8. Motorola i85 handset assembled with Sn-Ag$\mathrm{Cu}$ solder paste.

Motorola has published some details on the evaluation and qualification of the iDEN i85 handset (Figure 8) assembled with lead-free solder paste using the higher silver $\mathrm{Sn}-\mathrm{Ag}-\mathrm{Cu}$ alloy [31]. All indications are that $\mathrm{Pb}$-free did not introduce any major issues as compared to conventional Sn$\mathrm{Pb}$.

\section{Summary}

Lead-free soldering of electronic assemblies is becoming a reality with the passage of the WEEE and ROHS directives in Europe and continuing pressure from Japanese manufacturers, even in the face of conflicting information on its environmental benefits. The bulk of data indicates that $\mathrm{Pb}$ free soldering is a process that, although not a direct drop in replacement, can be applied with minimal reliability risk. Many components are compatible with lead-free assembly, and the biggest roadblock is to have all components compatible with the assembly process as well as the composition limits. As more companies gain experience in designing and building lead-free products, this will raise the maturity of lead-free technology into the mainstream.

\section{Acknowledgements}

The author would like to thank those at Motorola including Denny Miller, Kingshuk Banerji, Vahid Goudarzi, Gold Goudarzi, and Donna Vonderstrasse as well as many persons involved with the NEMI $\mathrm{Pb}$-free Solder project including John Sohn, Carol Handwerker, Rich Parker, Rick Charbonneau, Jasbir Bath, Ron Gedney and Cynthia Williams to which I am indebted.

\section{References}

1. Baggio, T., "The Panasonic Mini Disk Player: Turning a New Leaf in a Lead-Free Market, ," Proc. IPC Works: An International Summit on Lead-free Electronics Assemblies, 1999.

2. Joint text approved by the Conciliation Committee on Directive of the European Parliament and of the Council on waste electrical and electronic equipment (WEEE), http://www.icer.org.uk/Draft $\% 20$ WEEE $\% 20$ Conciliation $\%$ 20text.pdf

3. Joint text approved by the Conciliation on Directive of the European Parliament and of the Council on the restriction of the use of certain hazardous substances in electrical and e 1 e c equirpment i c http://www.icer.org.uk/Draft $\% 20$ ROHS $\% 20$ Conciliation $\%$ 20text.pdf

4. Bradley, E. et al, "Lead-free Project Focuses on Electronic Assemblies", Advanced Packaging, Feb. 2000, pp. 34-42.

5. NCMS Lead-Free Solder Project: Final Report, National Center for Manufacturing Sciences, 1997.

6. Lead-free, High-temperature, Fatigue-resistant Solder, Final Report, National Center for Manufacturing Sciences, 2001.

7. Warwick, M., "Implementing Lead-Free SolderingEuropean Consortium Research," Multicore Solders Report. Found at http://www.loctite.com/pdf/Leadfree European Consortium.pdf

8. Geibeg, J., "Why Industry Needs a Life Cycle Environmental Impact Evaluation of Tin-Lead and Lead Free Solder," Proc. Intl. Conf. On Lead-free Electronic Components and Assemblies, IPC, 2002.

9. Smith, E., "Environmental Impacts and Toxicity of Lead Free Solders," Proc. IPC Works: An International Summit on Lead-free Electronics Assemblies, 1999.

10. Tanokura, Y., "Race for Pb-Free Solder Splits over Bi Contents," Nikkei Electronics Asia, February 2001. 
11. Yoon, S.W. and H. M. Lee, "A Thermodynamic Study of Phase Equilibria in the $\mathrm{Sn}-\mathrm{Bi}-\mathrm{Pb}$ Solder System," Calphad, vol. 22, No. 2 (1998), pp. 167-178.

12. Mei, Z. et al, "Thermal Reliability of 58Bi-42Sn Solder Joints on Pb-Containing Surfaces", Proc. Design \& Rel. of Solders and Solder Interc., TMS, 1997, p. 229239.

13. Bradley, E., and J. Hranisavljevic, "Characterization of the Melting and Wetting of Sn-Ag-X Solders", IEEE Transactions on Electronics Packaging Manufacturing, vol. 24, 2001, pp. 255-260.

14. Moon, K.W. et al, "The Effect of $\mathrm{Pb}$ Contamination on the Solidification Behavior of Sn-Bi Solders," $J$. Electronic Materials, vol. 30, (2001) pp. 45-52.

15. Japan Electronics and Information Technology Industries Association (JEITA), 2002 Lead-Free Roadmap.

16. Bath, J. et al, "Research Update: Lead Free Solder Alternatives," Circuits Assembly, vol.11, No.5 (May 2000), pp 31-40.

17. Nimmo, K., "Worldwide Environmental Issues in Electronics and the Transition to Lead-free Proc. IPC Works: An International Summit on Lead-free Electronics Assemblies, 1999.

18. Sohn, J., "Lead Free Solder Joint Overview," IPC/NEMI Symposium on Lead-free Electronics, Sept. 19, 2002, Montreal.

19. Farooq, M. et al, Evaluation of $\operatorname{Lead}(\mathrm{Pb})$-free Ceramic Ball Grid Array (CBGA): Wettability, Microstructure and Reliability," Proc 51 ${ }^{\text {st }}$ Electronic Components and Technology Conf, 2001, pp. 978-986.

20 . Syed, A., "Reliability of Lead-Free Solder Connections for Area-Array Packages," Proc. APEX Tech. Conf., 2001.

21. Kanchanomai, C. et al, "Low cycle fatigue test for solders using non-contact digital image measurement system," International Journal of Fatigue, vol. 24 (2002) pp. 57-67.

22. Sohn, J., "Lead Free Reliability Team Status," IPC A P E X F o r u m, 2002. http://www.nemi.org/newsroom/apex2002/RELIABILITYSohn.pdf

23. Bradley, E., "NEMI Pb-free Interconnect Task Group Report," Proc. IPC Works: An International Summit on Lead-free Electronics Assemblies, 1999.

$24 . \quad$ Parker, R., "The Next No-Lead Hurdle: the Components Supply Chain," Circuitree, Aug. 2001.

25. Parker, R., "Lead Free Component Team Status," A P FE oXr2001.m,

http://www.nemi.org/newsroom/Presentations/APEX/Lead Free/PbDelco.pdf

26. Swan, G. et al, "Development of Lead-Free Peripheral Leaded and PBGA Components to Meet MSL3 at $260^{\circ} \mathrm{C}$ Peak Reflow Profile," Proc. APEX Tech. Conf., 2001.

27. NEMI tin whisker project information at http://www.nemi.org/projects/ese/tin whisker.html

28. Nakadaira, Y. et al, "Pb-free Plating for Peripheral / Leadframe Packages," Proc. Eco-Design, 2001, pp. 213 218.

29. Trumble, B., "Get the Lead Out!" IEEE Spectrum, Vol. 35, May 1998, pp. $55-60$.
30. Laine-Ylijoki, T. et al, "Development and Validation of a Lead-Free Alloy for Solder Paste Applications", IEEE Transactions CPMT-Part C, vol. 20 (1997), pp. 194198.

31. Goudarzi, V., "Lead Free Solder Paste Evaluation and Implementation in Personal Communication Products," Proc. Intl. Conf. On Lead-free Electronic Components and Assemblies, IPC, 2002. 